\title{
Synthesis, Structural Elucidation and Anti-Microbial Screening of Benzimidazole Incorporated $S$-Triazinyl Derivatives
}

\author{
JYOTINDRA MAHYAVANSHI ${ }^{*}$, MAHARSHI SHUKLA ${ }^{2}$, \\ AMANULLAKHAN $^{2}$ PATHAN $^{2}$, RAHUL SHAH ${ }^{2}$ and JAYESH JADHAV ${ }^{2}$ \\ ${ }^{1}$ Department of Chemistry, Sankalchand Patel University, Visnagar-384315, India \\ ${ }^{2}$ Department of Chemistry, \\ Hemchandracharya North Gujarat University, Patan- 384265, India \\ mjyotindra44@gmail.com
}

Received 14 November 2016/ Accepted 8 December 2016

\begin{abstract}
A series of ten 2,4,6-trisubstituted $s$-triazines was synthesized with benzimidazole, morpholine and different substituted arylamine derivatives. All the products were characterized by conventional and instrumental methods. The compounds were examined for their in vitro microbial activity against gram negative bacteria and gram positive bacteria. Structure of final compound was confirmed by IR, ${ }^{1} \mathrm{H}$ NMR and mass spectra.
\end{abstract}

Keywords: 2,4,6-Trichloro-1,3,5-triazine, Morpholine, Benzimidazole, Substituted aryl amine, Antimicrobial activity

\section{Introduction}

Due to the increasing number of multidrug resistant developed by the microbes, Currently used antimicrobial agents are ineffective and antibacterial and antifungal diseases are very common, therefore, the design and synthesis of novel antimicrobial molecules has been of enormous interest in recent years. Literature survey reveals that substituted $s$-triazine derivatives are associated with a number of pronounced biological activities ${ }^{1-4}$. The biological activity is a function of physicochemical properties of the targeted molecule and this assessment is based on the kinds of chemicals that might fit into an active site ${ }^{5,6}$.

During the past few decades, 1,3,5-triazines have been grabbing the attention of the synthetic chemists for their wide gamut of biological activities, such as antimicrobial ${ }^{7,8}$, antiprotozoal $^{9}$, anticancer ${ }^{10}$, antimalarial ${ }^{11}$ and antiviral ${ }^{12}$ activity.

All of the $s$-triazine derivatives that have wide practical application are 2,4,6-mono,di or tri-substituted symmetrical and unsymmetrical compounds bearing different substituents. The most important reagents for obtaining these compounds are cyanuric chloride because of the reactivity of its chlorine atoms towards nucleophiles ${ }^{13}$. 
We had synthesized the $s$-triazinyl derivatives in combination with $p$-hydroxybenzonitrile and 8-hydroxy quinoline in our previous work we had found that most of the compounds showing good to moderate activity against bacterial species ${ }^{14}$.

Our idea was to combine, benziimidazole, morpholine and s-triazine nucleus, using cyanuric chloride and various amines. As substituted $s$-triazines derivatives, these compounds remain an attractive proposition, with their significant biological activities. And further incorporation with commercial drug viz. ciprofloxacin, enabling access to a wide array of structures with interesting antimycrobacterial activity.

\section{Experimental}

All the chemicals were purchased from Himedia chemical Pvt. Ltd. And melting points were determined using open capillary tubes on electronic apparatus and were uncorrected. The IR spectra (4000-400 $\mathrm{cm}^{-1}$ ) of synthesized compounds were recorded on Shimadzu 8400-s FTIR spectrometer with $\mathrm{KBr}$ pellets. To monitor the reactions, establish the identity, purity of reactants and products, thin layer chromatography was performed on TLC coated with silica gel using appropriate mobile phase system and spots were visualized under UV radiation.

Nuclear magnetic resonance spectra was recorded using Bruker $400 \mathrm{MHz}$ model spectrometer using DMSO as a solvent and TMS as internal standard (Chemical shifts in $\delta$ ppm). All new compounds were subjected to elemental analysis and the results obtained were in acceptable range.

\section{General Procedure}

\section{Synthesis of1-(4,6-dichloro-1,3,5-triazin-2-yl)-1H-benzimidazole(1)}

To a stirred solution of cyanuric chloride $(0.1 \mathrm{~mol})$ in acetone $(100 \mathrm{~mL})$ at $0-5{ }^{\circ} \mathrm{C}$, the solution of benzimidazole $(0.1 \mathrm{~mole})$ in acetone $(90 \mathrm{~mL})$ was added drop wise in two hours. During the reaction $10 \% \mathrm{NaHCO}_{3}$ was added to maintain the reaction mixture neutral. The progress of reaction was monitored by TLC using actone: toluene (2:8) as eluent. After the completion of the reaction, the stirring was stopped and the solution was treated with crushed ice. The product obtained was filtered and dried (Scheme 1). The crude product was purified and recrystallization from alcohol. The yield was $85 \%$ having melting point $191{ }^{\circ} \mathrm{C}$.

\section{Synthesis of1-[4-chloro-6-(morpholin-4-yl)-1,3,5-triazin-2-yl]-1H benzimidazole(2)}

To a stirred solution of 1-(4,6-dichloro-1,3,5-triazin-2-yl)- $1 H$-benzimidazolein acetone at room temperature the solution of morpholine in acetone was slowly added in $2 \mathrm{~h}$ the temperature was raised to $45{ }^{\circ} \mathrm{C}$ during $2 \mathrm{~h} .10 \%$ Solution of $\mathrm{NaHCO}_{3}$ was added to maintain the reaction mixture neutral and further maintained for $2 \mathrm{~h}$. The progress of reaction was monitored by TLC using Acetone : Toulene $(2: 8)$ after completion of reaction the solution was poured into ice cold water the solid product which was obtained after filtration was dried and recrystallization from absolute alcohol to give the title compound the yield was $75 \%$ having melting point $228{ }^{\circ} \mathrm{C}$.

Synthesis of 4-(1H-benzimidazol-1-yl)-N-(4-aryl)-6-(morpholin-4-yl)-1,3,5-triazin2-amine derivatives $(3 a-j)$

To a solution of 1-[4-chloro-6-(morpholin-4-yl)-1,3,5-triazin-2-yl]-1H-benzimidazole (0.01 mol in 1,4-dioxane $20 \mathrm{~mL}$ ) appropriate different substituted aryl amines derivatives was added and the reaction mixture was refluxed for $6-10 \mathrm{~h} .10 \% \mathrm{NaHCO}_{3}$ was used for 
neutralization of the reaction mixture after the completion of reaction it was treated with crushed ice and neutralized by dil. $\mathrm{HCl}$ the precipitate thus obtained were dried and recrystallization form absolute alcohol.

Step-1

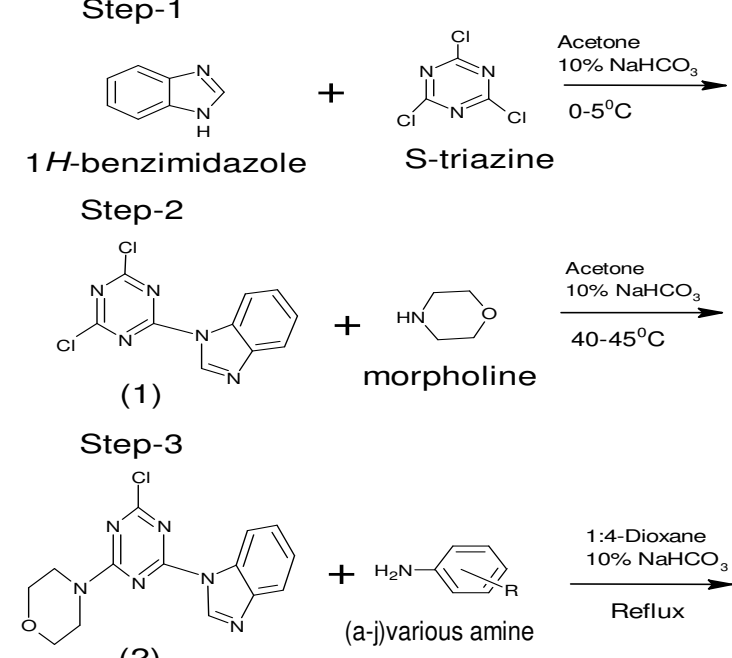

(2)<smiles>Clc1nc(Cl)nc(-n2cnc3ccccc32)n1</smiles>

(1)<smiles>Clc1nc(N2CCOCC2)nc(-n2cnc3ccccc32)n1</smiles>

(2)<smiles>c1ccc(Nc2nc(N3CCOCC3)nc(-n3cnc4ccccc43)n2)cc1</smiles>

(3) $a-j$

Various amines<smiles>Cc1ccc(N)cc1</smiles><smiles>Nc1ccc(F)cc1</smiles><smiles>COc1ccc(N)cc1</smiles><smiles>CN(C)c1ccc(Br)cc1</smiles><smiles>[Mg][Mg]</smiles><smiles>Nc1ccc(Cl)cc1</smiles><smiles>C1CCNC1</smiles><smiles>Nc1ccccc1</smiles><smiles>Nc1ccc([N+](=O)[O-])cc1</smiles>
(e) (f)<smiles>Nc1ccc(Cl)cc1</smiles><smiles>Nc1ccc(Br)c(Br)c1</smiles>

Scheme 1. Reaction pathway

(a) 4-(1H-benzimidazol-1-yl)- $N$-(4-methylphenyl)-6-(morpholin-4-yl)-1,3,5-triazin-2amine $858 \mathrm{~cm}^{-1}(-\mathrm{C}=\mathrm{N}-)$ stretching in $s$-triazine, $1617-1447 \mathrm{~cm}^{-1}(-\mathrm{C}=\mathrm{C}-)$ and $(-\mathrm{C}=\mathrm{N}-)$ stretching, $1243 \mathrm{~cm}^{-1}(-\mathrm{C}-\mathrm{O}-)$ stretching in morpholine, $1114 \mathrm{~cm}^{-1}(-\mathrm{C}-\mathrm{N}-)$ stretching in morpholine, $2917 \mathrm{~cm}^{-1}(-\mathrm{CH})$ stretching in methyl, $3414 \mathrm{~cm}^{-1}(-\mathrm{NH})$ stretching in secondary amine, $1172 \mathrm{~cm}^{-1}$ (-C-O-) stretching, ${ }^{1} \mathrm{H}$ NMR (in ppm): 9.85, singlet, Ar-N $\underline{H}$, (1H),3.31, singlet, $\mathrm{Ar}-\mathrm{CH}_{3},(3 \mathrm{H}), 8.66$, singlet, (-Cㅡ-imidazole), (1H),7.89-6.87, doublet, Ar- $\underline{\mathrm{H}},(2 \mathrm{H}), 7.35-7.27$, doublet, Ar- $\underline{\mathrm{H}},(2 \mathrm{H}), 7.76-7.55$, multiplates, Ar- $\underline{\mathrm{H}},(4 \mathrm{H})$, 3.84, multiplates, morpholine, $(8 \mathrm{H})$. Mass: $(\mathrm{m} / \mathrm{z}) 388.2(\mathrm{M}+1)$. 
(b) 4-(1H-benzimidazol-1-yl)- $N$-(4-fluorophenyl)-6-(morpholin-4-yl)-1,3,5-triazin-2-amine $855 \mathrm{~cm}^{-1}(-\mathrm{C}=\mathrm{N}-)$ stretching in $s$-triazine, $1627-1422 \mathrm{~cm}^{-1}(-\mathrm{C}=\mathrm{C}-)$ and $(-\mathrm{C}=\mathrm{N}-)$ stretching, $1243 \mathrm{~cm}^{-1}$ (-C-O-) stretching in morpholine, $1124 \mathrm{~cm}^{-1}(-\mathrm{C}-\mathrm{N}-)$ stretching in morpholine, $2917 \mathrm{~cm}^{-1}(-\mathrm{CH})$ stretching in methyl, $3416 \mathrm{~cm}^{-1}(-\mathrm{NH})$ stretching in secondary amine, $1172 \mathrm{~cm}^{-1}$ (-C-O-) stretching, ${ }^{1} \mathrm{H}$ NMR (in ppm): 9.55, singlet, $\mathrm{Ar}-\mathrm{N} \underline{\mathrm{H}}$,

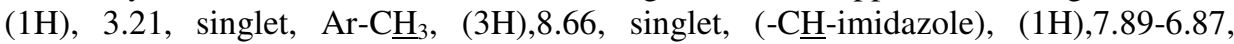
doublet, Ar- $\underline{\mathrm{H}},(2 \mathrm{H}), 7.35-7.27$, doublet, $\mathrm{Ar}-\underline{\mathrm{H}},(2 \mathrm{H}), 7.76-7.55$, multiplates, Ar- $\underline{\mathrm{H}},(4 \mathrm{H})$, 3.84, multiplates, morpholine, $(8 \mathrm{H})$.Mass: $(\mathrm{m} / \mathrm{z}) 392.40(\mathrm{M}+1)$.

(c) 4-(1H-benzimidazol-1-yl)- $N$-(4-methoxyphenyl)-6-(morpholin-4-yl)-1,3,5-triazin-2amine $858 \mathrm{~cm}^{-1}(-\mathrm{C}=\mathrm{N}-)$ stretching in $s$-triazine, $1617-1447 \mathrm{~cm}^{-1}(-\mathrm{C}=\mathrm{C}-)$ and $(-\mathrm{C}=\mathrm{N}-)$ stretching, $1243 \mathrm{~cm}^{-1}$ (-C-O-) stretching in morpholine, $1114 \mathrm{~cm}^{-1}(-\mathrm{C}-\mathrm{N}-)$ stretching in morpholine, $2917 \mathrm{~cm}^{-1}(-\mathrm{CH})$ stretching in methyl, $3414 \mathrm{~cm}^{-1}(-\mathrm{NH})$ stretching in secondary amine, $1172 \mathrm{~cm}^{-1}$ (-C-O-) stretching, ${ }^{1} \mathrm{H}$ NMR (in ppm): 9.85, singlet, $\mathrm{Ar}-\mathrm{N} \underline{\mathrm{H}}$, $(1 \mathrm{H}), 3.31$,singlet, $\mathrm{Ar}-\mathrm{C}_{3},(3 \mathrm{H}), 8.66$, singlet, $(-\mathrm{C} \underline{H}-$-imidazole $),(1 \mathrm{H}), 7.89-6.87$, doublet, Ar- $\underline{\mathrm{H}},(2 \mathrm{H}), 7.35-7.27$, doublet, Ar- $\underline{\mathrm{H}},(2 \mathrm{H}), 7.76-7.55$, multiplates, Ar- $\underline{\mathrm{H}},(4 \mathrm{H}), 3.84$, multiplates, morpholine, $(8 \mathrm{H})$.Mass: $(\mathrm{m} / \mathrm{z}) 403.43(\mathrm{M}+1)$.

(d) 4-(1H-benzimidazol-1-yl)- $N$-(4-bromophenyl)-6-(morpholin-4-yl)-1,3,5-triazin-2-amine $859 \mathrm{~cm}^{-1}(-\mathrm{C}=\mathrm{N}-)$ stretching in $s$-triazine, 1622-1428 $\mathrm{cm}^{-1}(-\mathrm{C}=\mathrm{C}-)$ and $(-\mathrm{C}=\mathrm{N}-)$ stretching, $1233 \mathrm{~cm}^{-1}(-\mathrm{C}-\mathrm{O}-)$ stretching in morpholine, $1112 \mathrm{~cm}^{-1}(-\mathrm{C}-\mathrm{N}-)$ stretching in morpholine, $2916 \mathrm{~cm}^{-1}(-\mathrm{CH})$ stretching in methyl, $3412 \mathrm{~cm}^{-1}(-\mathrm{NH})$ stretching in secondary amine, $1172 \mathrm{~cm}^{-1}$ (-C-O-) stretching, ${ }_{1}^{1} \mathrm{H} \mathrm{NMR}(\mathrm{in} \mathrm{ppm}): 9.88$, singlet,Ar-N $\underline{\mathrm{H}}$, $(1 \mathrm{H}), 3.35$, singlet, $\mathrm{Ar}-\mathrm{C}_{3},(3 \mathrm{H}), 8.67$, singlet, (-Cㅡ-imidazole), $(1 \mathrm{H}), 7.88-6.85$, doublet, Ar- $\underline{H},(2 \mathrm{H}), 7.35-7.27$, doublet, Ar- $\underline{H},(2 \mathrm{H}), 7.77-7.56$,multiplates, Ar- $\underline{H},(4 \mathrm{H}), 3.82$, multiplates, morpholine, $(8 \mathrm{H})$.Mass: $(\mathrm{m} / \mathrm{z}) 453.30(\mathrm{M}+1)$.

(e) 4-(1H-benzimidazol-1-yl)- $N$-(4-chlorophenyl)-6-(morpholin-4-yl)-1,3,5-triazin-2-amine $853 \mathrm{~cm}^{-1}(-\mathrm{C}=\mathrm{N}-)$ stretching in $s$-triazine, $1618-1427 \mathrm{~cm}^{-1}(-\mathrm{C}=\mathrm{C}-)$ and $(-\mathrm{C}=\mathrm{N}-)$ stretching, $1283 \mathrm{~cm}^{-1}(-\mathrm{C}-\mathrm{O}-)$ stretching in morpholine, $1124 \mathrm{~cm}^{-1}(-\mathrm{C}-\mathrm{N}-)$ stretching in morpholine, $2927 \mathrm{~cm}^{-1}(-\mathrm{CH})$ stretching in methyl, $3424 \mathrm{~cm}^{-1}(-\mathrm{NH})$ stretching in secondary amine, $1175 \mathrm{~cm}^{-1}$ (-C-O-) stretching, ${ }_{1}^{1} \mathrm{H}$ NMR(in ppm): 9.75, singlet,Ar-N $\underline{H}$, (1H), 3.21, singlet, $\mathrm{Ar}-\mathrm{C}_{3},(3 \mathrm{H}), 8.59$, Singlet, (-Cㅐ-imidazole), $(1 \mathrm{H}), 7.86-6.87$, doublet, Ar- $\underline{H}$, (2H), 7.25-7.27, doublet, Ar- $\underline{H},(2 \mathrm{H}), 7.76-7.55$,multiplates, Ar- $\underline{H},(4 \mathrm{H}), 3.84$, multiplates, morpholine, $(8 \mathrm{H})$. Mass: $(\mathrm{m} / \mathrm{z}) 407.85(\mathrm{M}+1)$.

(f) 4-(1H-benzimidazol-1-yl)-6-(morpholin-4-yl)- $N$-phenyl-1,3,5-triazin-2-amine $861 \mathrm{~cm}^{-1}$ $(-\mathrm{C}=\mathrm{N}-)$ stretching in $s$-triazine, $1627-1420 \mathrm{~cm}^{-1}(-\mathrm{C}=\mathrm{C}-)$ and $(-\mathrm{C}=\mathrm{N}-)$ stretching, $1243 \mathrm{~cm}^{-1}$ (-C-O-) stretching in morpholine, $1112 \mathrm{~cm}^{-1}(-\mathrm{C}-\mathrm{N}-)$ stretching in morpholine, $2920 \mathrm{~cm}^{-1}(-\mathrm{CH})$ stretching in methyl, $3423 \mathrm{~cm}^{-1}(-\mathrm{NH})$ stretching in secondary amine, $1172 \mathrm{~cm}^{-1}(-\mathrm{C}-\mathrm{O}-)$ stretching, ${ }^{1} \mathrm{H}$ NMR (in ppm): 9.65, singlet,Ar-N $\underline{\mathrm{H}},(1 \mathrm{H}), 3.21$, singlet, $\mathrm{Ar}-\mathrm{CH}_{3},(3 \mathrm{H}), 8.62$,singlet, (-CH-imidazole), (1H),7.79-6.87, doublet, Ar- $\underline{\mathrm{H}}$, (2H),7.45-7.27, doublet, Ar- $\underline{\mathrm{H}}, \quad(2 \mathrm{H}), 7.73-7.52$,multiplates, $\mathrm{Ar}-\underline{\mathrm{H}}, \quad(4 \mathrm{H}), \quad 3.74$, multiplates, morpholine, $(8 \mathrm{H})$. Mass: $(\mathrm{m} / \mathrm{z}) 374.41(\mathrm{M}+1)$.

(g) 4-(1H-benzimidazol-1-yl)-6-(morpholin-4-yl)- $N$-(4-nitrophenyl)-1,3,5-triazin-2-amine $852 \mathrm{~cm}^{-1}(-\mathrm{C}=\mathrm{N}-)$ stretching in $s$-triazine, 1622-1441 $\mathrm{cm}^{-1}(-\mathrm{C}=\mathrm{C}-)$ and $(-\mathrm{C}=\mathrm{N}-)$ stretching, $1243 \mathrm{~cm}^{-1}(-\mathrm{C}-\mathrm{O}-)$ stretching in morpholine, $1113 \mathrm{~cm}^{-1}(-\mathrm{C}-\mathrm{N}-)$ stretching in morpholine, $2913 \mathrm{~cm}^{-1}(-\mathrm{CH})$ stretching in methyl, $3422 \mathrm{~cm}^{-1}(-\mathrm{NH})$ stretching in secondary amine, $1172 \mathrm{~cm}^{-1}$ (-C-O-) stretching, ${ }^{1} \mathrm{H}$ NMR (in ppm): 9.81, singlet, $\mathrm{Ar}-\mathrm{N} \underline{\mathrm{H}}$, (1H), 3.11, singlet,Ar- $\underline{\mathrm{H}}_{3},(3 \mathrm{H}), 8.67$, singlet, (-Cㅡ-imidazole), (1H), 7.91-6.88, doublet, 
Ar- $\underline{H},(2 \mathrm{H}), 7.35-7.27$, doublet, Ar- $\underline{\mathrm{H}},(2 \mathrm{H}), 7.77-7.53$, multiplates, $\operatorname{Ar}-\underline{\mathrm{H}},(4 \mathrm{H}), 3.88$, multiplates, morpholine, $(8 \mathrm{H})$.Mass: $(\mathrm{m} / \mathrm{z}) 418.40(\mathrm{M}+1)$.

(h) 4-(1H-benzimidazol-1-yl)- $N$-(4-chloro-3-fluorophenyl)-6-(morpholin-4-yl)-1,3,5-triazin -2-amine $855 \mathrm{~cm}^{-1}(-\mathrm{C}=\mathrm{N}-)$ stretching in $s$-triazine, $1612-1437 \mathrm{~cm}^{-1}(-\mathrm{C}=\mathrm{C}-)$ and $(-\mathrm{C}=\mathrm{N}-)$ stretching, $1223 \mathrm{~cm}^{-1}(-\mathrm{C}-\mathrm{O}-)$ stretching in morpholine, $1124 \mathrm{~cm}^{-1}(-\mathrm{C}-\mathrm{N}-)$ stretching in morpholine, $2923 \mathrm{~cm}^{-1}(-\mathrm{CH})$ stretching in methyl, $3434 \mathrm{~cm}^{-1}(-\mathrm{NH})$ stretching in secondary amine, $1165 \mathrm{~cm}^{-1}$ (-C-O-) stretching, ${ }^{1} \mathrm{H}$ NMR(in ppm): 9.65, singlet, $\mathrm{Ar}-\mathrm{N} \underline{\mathrm{H}},(1 \mathrm{H}), 3.41$, singlet, $\mathrm{Ar}-\mathrm{C}_{3},(3 \mathrm{H}), 8.56$, singlet, (- $\mathrm{C} \underline{\mathrm{H}}$-imidazole), $(1 \mathrm{H})$, 7.88-6.86, doublet, Ar- $\underline{\mathrm{H}},(2 \mathrm{H}), 7.25-7.17$, doublet, Ar- $\underline{\mathrm{H}},(2 \mathrm{H}), 7.66-7.55$, multiplates, Ar$\underline{\mathrm{H}},(4 \mathrm{H}), 3.74$, multiplates, morpholine, $(8 \mathrm{H})$. Mass: $(\mathrm{m} / \mathrm{z}) 425.84(\mathrm{M}+1)$.

(i) 4-(1H-benzimidazol-1-yl)- $N$-(3-chlorophenyl)-6-(morpholin-4-yl)-1,3,5-triazin-2-amine $854 \mathrm{~cm}^{-1}(-\mathrm{C}=\mathrm{N}-)$ stretching in $s$-triazine, 1618-1427 $\mathrm{cm}^{-1}(-\mathrm{C}=\mathrm{C}-)$ and $(-\mathrm{C}=\mathrm{N}-)$ stretching, $1223 \mathrm{~cm}^{-1}(-\mathrm{C}-\mathrm{O}-)$ stretching in morpholine, $1124 \mathrm{~cm}^{-1}(-\mathrm{C}-\mathrm{N}-)$ stretching in morpholine, $2920 \mathrm{~cm}^{-1}(-\mathrm{CH})$ stretching in methyl, $3424 \mathrm{~cm}^{-1}(-\mathrm{NH})$ stretching in secondary amine, $1171 \mathrm{~cm}^{-1}$ (-C-O-) stretching, ${ }^{1} \mathrm{H} \mathrm{NMR}($ in ppm): 9.75 , singlet,Ar-N $\underline{\mathrm{H}}$, (1H), 3.21, singlet, $\mathrm{Ar}-\mathrm{C}_{3},(3 \mathrm{H}), 8.56$, singlet, (-Cㅡ-imidazole), $(1 \mathrm{H}), 7.79-6.67$, doublet, Ar- $\underline{H},(2 \mathrm{H}), 7.35-7.27$, doublet, $\operatorname{Ar}-\underline{\mathrm{H}},(2 \mathrm{H}), 7.76-7.55$, multiplates, $\mathrm{Ar}-\underline{\mathrm{H}},(4 \mathrm{H}), 2.94$, multiplates, morpholine, $(8 \mathrm{H})$. Mass: $(M / Z) 407.88(\mathrm{M}+1)$.

(j) 4-(1H-benzimidazol-1-yl)- $N$-(3-bromophenyl)-6-(morpholin-4-yl)-1,3,5-triazin-2-amine $853 \mathrm{~cm}^{-1}(-\mathrm{C}=\mathrm{N}-)$ stretching in $S$-triazine, 1613-1427 $\mathrm{cm}^{-1}(-\mathrm{C}=\mathrm{C}-)$ and $(-\mathrm{C}=\mathrm{N}-)$ stretching, $1244 \mathrm{~cm}^{-1}(-\mathrm{C}-\mathrm{O}-)$ stretching in morpholine, $1109 \mathrm{~cm}^{-1}(-\mathrm{C}-\mathrm{N}-)$ stretching in morpholine, $2913 \mathrm{~cm}^{-1}(-\mathrm{CH})$ stretching in methyl, $3412 \mathrm{~cm}^{-1}(-\mathrm{NH})$ stretching in secondary amine, $1172 \mathrm{~cm}^{-1}$ (-C-O-) stretching, ${ }^{1} \mathrm{H} \mathrm{NMR}($ in $\mathrm{ppm}): 9.86$, singlet, $\mathrm{Ar}-\mathrm{N} \underline{\mathrm{H}}$, (1H), 2.91,singlet, $\mathrm{Ar}-\underline{\mathrm{C}}_{3},(3 \mathrm{H}), 8.76$, singlet, (-Cㅡㅡ-imidazole), $(1 \mathrm{H}), 7.79-6.77$, doublet, Ar- $\underline{H},(2 \mathrm{H}), 7.45-7.37$, doublet, Ar- $\underline{\mathrm{H}},(2 \mathrm{H}), 7.77-7.54$,multiplates, $\operatorname{Ar}-\underline{\mathrm{H}},(4 \mathrm{H}), 3.88$, multiplates, morpholine, $(8 \mathrm{H})$. Mass: $(\mathrm{m} / \mathrm{z}) 453.2(\mathrm{M}+1)$.

\section{Results and Discussion}

3[4-(1H-benzimidazol-1-yl)- $N$-(4-aryl)-6-(morpholin-4-yl)-1,3,5-triazin-2-amine] (Figure 1) were obtained in $66-83 \%$ yield by reacting cyanuric chloride with bezimidazole in first step (Scheme 1) at low temperature and then in second step at room temperature it was reacted with morpholine, in last step at reflux temperature it was reacted with various amine(3a-j). Mass spectral data support the proposed structures. The mass spectrum showed various characteristic peaks. A peak at $\mathrm{m} / \mathrm{z} 388.2$ was assigned to the molecular ion.

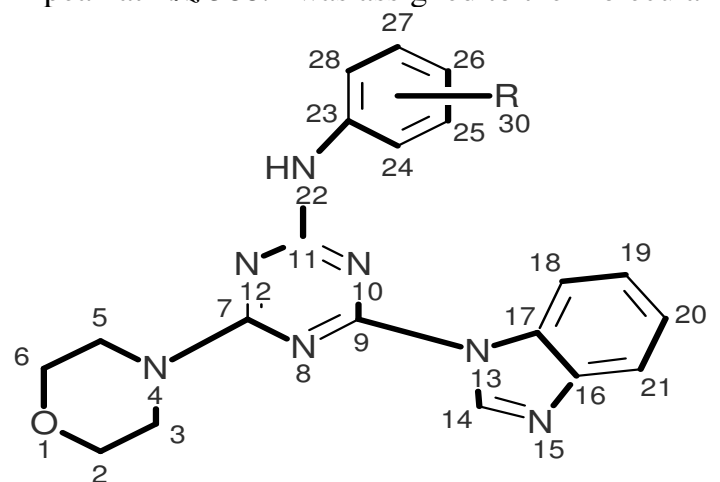

Figure 1. Structure of compound $\mathbf{3}(\mathbf{a}-\mathbf{j})$ 
The FTIR spectrum showed absorption bands at $858 \mathrm{~cm}^{-1}-\mathrm{C}=\mathrm{N}$ - Stretching in $s$-triazine, 1617-1447 $\mathrm{cm}^{-1}-\mathrm{C}=\mathrm{C}$ - and $-\mathrm{C}=\mathrm{N}$ - stretching, $1243 \mathrm{~cm}^{-1}-\mathrm{C}-\mathrm{O}$ - stretching in morpholine, $1114 \mathrm{~cm}^{-1}-\mathrm{C}-\mathrm{N}$ - stretching in morpholine, $2917 \mathrm{~cm}^{-1}-\mathrm{CH}$ stretching in methyl, $3414 \mathrm{~cm}^{-1}$ $\mathrm{NH}$ stretching in secondary amine, $1172 \mathrm{~cm}^{-1}$-C-O- stretching.

The ${ }^{1} \mathrm{H}$ NMR spectrums of (5a-j) showed characteristic signals at 7.09 to $7.44 \mathrm{ppm}$ for the aromatic protons. A signal at $9.85 \mathrm{ppm}$ was assigned to the amine proton. A signal at $2.31 \mathrm{ppm}$ was assigned to the methyl proton. The singlet 3.92-3.95 ppm was assigned to the methoxy protons, respectively.

\section{Antimicrobial activity}

The compound 1-10 were tested for their antimicrobial activity against gram positive bacteria and gram negative bacteria and the fungal strains the resulted MIC values are depicted in the below Table 1. The sample were tested by standard protocol like micro dilution/broth titer method the screening of the antimicrobial activity was carried out by diluting the solution and preparing the sets consecutively from 1000, 500, 250, 125, 62.5, $31.25,15.62$ up to $7.8 \mathrm{mg} / \mathrm{mL}$.

Table 1. Antimicrobial activity of the synthesized compounds

\begin{tabular}{ccccc}
\hline & \multicolumn{3}{c}{ Minimum inhibitory concentration, $\mu \mathrm{g} / \mathrm{mL}$} \\
\cline { 2 - 5 } Code No. & \multicolumn{2}{c}{ Gram positive bacteria } & \multicolumn{2}{c}{ Gram negative bacteria } \\
\cline { 2 - 5 } & Bacillus pumilus & $\begin{array}{c}\text { Bacillus } \\
\text { cereus } \\
\text { MTCC-9584 }\end{array}$ & $\begin{array}{c}\text { Proteus } \\
\text { Mirabilis } \\
\text { MTCC-9762 }\end{array}$ & $\begin{array}{c}\text { Escherichia } \\
\text { coli } \\
\text { MTCC-600 }\end{array}$ \\
\hline JM-C1 & 500 & 1000 & 1000 & 1000 \\
JM-C2 & 1000 & 1000 & 500 & 500 \\
JM-C3 & 500 & 1000 & 1000 & 1000 \\
JM-C4 & 62.5 & 250 & 250 & 1000 \\
JM-C5 & 250 & 500 & 250 & 500 \\
JM-C6 & 125 & 500 & 500 & 1000 \\
JM-C7 & $1000>$ & 1000 & 500 & $1000>$ \\
JM-C8 & 1000 & 250 & 1000 & 500 \\
JM-C9 & 500 & $1000>$ & $1000>$ & $1000>$ \\
JM-C10 & $1000>$ & 1000 & 500 & $1000>$ \\
Ciproflox & 62.5 & 62.5 & 62.5 & 62.5 \\
\hline
\end{tabular}

\section{Cup plates or cylinder plate method}

This method depends on the diffusion of an antibiotic from a vertical cavity or a cylinder, through the solidified agar layer in a petri plate. The growth of test microorganism is inhibited entirely in a circular area or zone around the cavity or cylinder containing a solution of the antibiotic. A liquefied assay medium $\left(43\right.$ to $\left.45{ }^{\circ} \mathrm{C}\right)$ is inoculated by suspension of test microorganisms and the inoculated medium is poured immediately into sterile petri plate or pre-prepared agar plates by using an assay medium and then spread the test culture or microorganisms on the surface of plates.

Solution of known concentration of the standard preparation and the test antibiotic are prepared in appropriate solutions. This solution are added in sterile cavities or cylinders prepared in a solid medium. The volume of above solution added to each cavity or cylinder must be uniform and sufficient to fill the holes. 
The plates are left standings for 1 to 2 hours at room temperature or at $45^{\circ} \mathrm{C}$, as a period of pre-incubation diffusion to minimize the effects of variation in time between the applications of the different solutions. All plates are then incubated for about 18 to 24 hours at the temperature as per bacterial condition. The diameters or areas of the circular inhibition zones produced by standard and test antibiotic solutions are accurately measured.
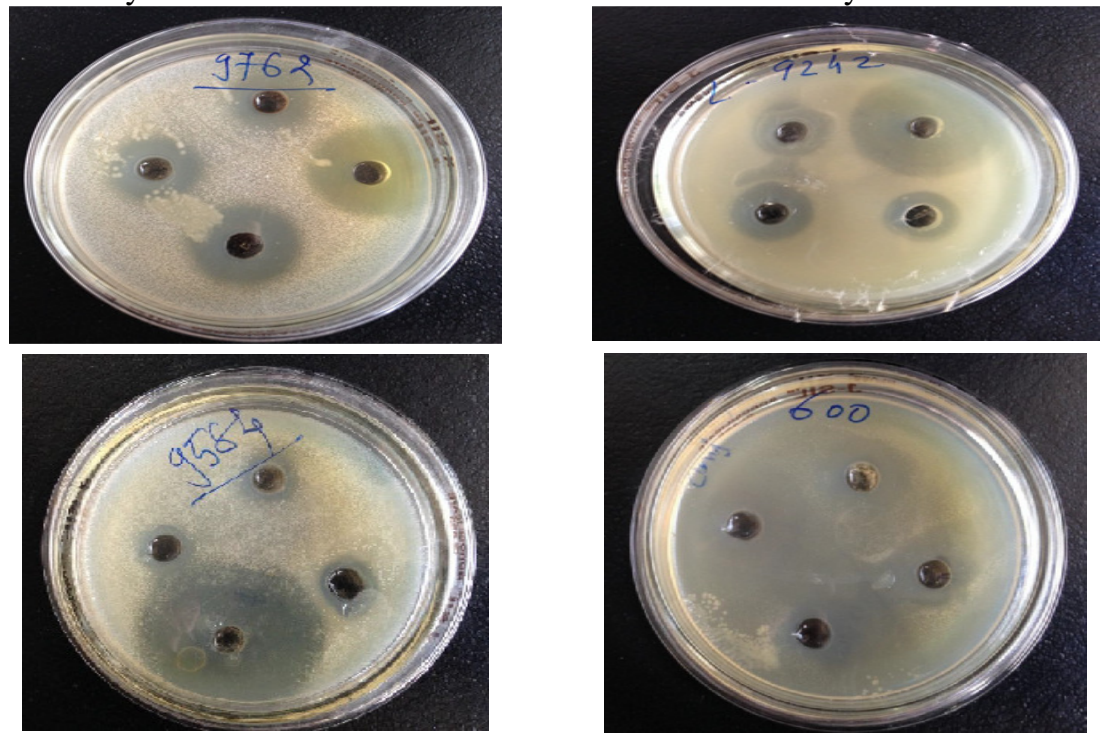

Figure 2. Antimicrobial activity image for the compounds JM-C4, C6, C5, C2

Results in the above table shows that an antibacterial activity of the synthesized compounds against gran positive bacteria Bacillus Pumilus were good. Compound JM-C4 was showing highest activity at the concentration of $62.5 \mu \mathrm{g} / \mathrm{Ml}$ which as equal to standard drugs. JM-C6 was also showing good activity (Figure 2). Compound JM-C5 was showed moderate activity as compared to standard one.JM-C1; JM-C3, JM-C9 and JM-C11 were showing poor activity as compare to standard. Activity of synthesized compounds against the gram positive bacteria Bacillus Cereus was found not that active as compared to standard drugs. The most of the compounds were found active at higher concentration. Proteus Mirabilis is a gram negative bacteria used for the antibacterial screening of the synthesized compounds. Compounds JM-C2, JM-C5 and JM-C7 were found poorly active to these bacteria. Other remaining compounds were showing activity at the higher concentration or not active against these bacteria. Activity of synthesized compounds against E. coli (MTCC600 ) was found poor most of the compounds were showing poor activity.

\section{Conclusion}

3[4-(1H-benzimidazol-1-yl)- $N$-(4-aryl)-6-(morpholin-4-yl)-1,3,5-triazin-2-amine] were obtained in $66-83 \%$ yield by reacting cyanuric chloride with bezimidazole in first step at low temperature and then in second step at room temperature it was reacted with morpholine, in last step at reflux temperature it was reacted with various amine(3a-j). Their structures were confirmed by infrared, ${ }^{1} \mathrm{H}$ - and mass spectrometric analysis. All the synthesized compound were screened against bacterial species the result showed that half of the compound having good activity against bacterial species while remaining compound were showed sowed moderate to poor activity against bacterial and fungal species. 


\section{Acknowledgement}

The authors are thankful to UGC, India for providing Fellowship to one of author Jyotindra Mahyavanshi. The authors are also thankful to Central Instrument and Maintenance facility (CIMF), Hemchandracharya North Gujarat University, Patan, India for IR spectra. The authors are offer their gratitude to Microcare laboratory, Surat, India for carrying out biological Screening and CDRI, Lukhnow, India for carrying out ${ }^{1} \mathrm{H}$ NMR, ${ }^{13} \mathrm{C}$ NMR and Mass Spectra.

\section{References}

1. Raval J P and Desai K R, E-J Chem., 2004, 1(5), 211-215; DOI:10.1155/2004/873425

2. Patel R B, Chikhalia K H, Pannecouque C and Clercq Erik de, J Braz Chem Soc., 2007, 18(2), 312-321; DOI:10.1590/S0103-50532007000200011

3. Kumar A, Srivastava K, Raja Kumar S, Puri S K, Chauhan Prem M S, Bioorg Med Chem Lett., 2008, 18(24), 6530-6533; DOI:10.1016/j.bmcl.2008.10.049

4. Singh B K, Mishra M, Saxena N, Yadav G P, Maulik P R, Sahoo M K, Gaur R L, Murthy P K and Tripathi R P, Eur J Med Chem., 2008, 43(12), 2717-2723; DOI:10.1016/j.ejmech.2008.01.038

5. Gubernator K and Bohm H J, Structure-Based Ligand Design, Methods and Principles in Medicinal Chemistry. Wiley-VCH Publishers, Weinheim, 1998, 15-95.

6. Weiner D B and William V, Chemical and Structural Approaches to Rational Drug Design. CRC, Boca Raton, FL, 1994, 12-85.

7. Zhou C, Min J, Zhigang L, Anne Y, Heather D, Tian G, Young-Tae C and Neville R K, Bioorg Med Chem Lett., 2008, 18(4), 1308-1311; DOI:10.1016/j.bmcl.2008.01.031

8. Srinivas K, Srinivas U, Bhanuprakash K, Harakishore K, Murthy U S N, Jayathirtha R V, Eur J Med Chem., 2006, 41(11), 1240-1246; DOI:10.1016/j.ejmech.2006.05.013

9. Alessandro B, Gorka J B, Mhairi L S, Vanessa Y, Reto B, Michael P B and Ian H G, J Med Chem., 2005, 48(17), 5570-5579; DOI:10.1021/jm050177+

10. Sergio M, Davide P, Paolo C, Nicoletta B, Diego M, Chem Med Chem., 2008, 3(6), 873-876; DOI:10.1002/cmdc.200700344

11. Rita M, Simona S, Giovanni S, Francesca V, Lisa D V, J Med Chem., 2004, 47(19), 4649-4652; DOI:10.1021/jm0495374

12. Yuan-Zhen X, Fen-Er C, Jan B, Erik D C and Christophe P, Eur J Med Chem., 2008, 43(6), 1230-1236; DOI:10.1016/j.ejmech.2007.08.001

13. Blotny G, Tetrahedron, 2006, 62(41), 9507-9522; DOI:10.1016/j.tet.2006.07.039

14. Mahyavanshi J B and Parmar K A, J Chem Biol Phy Sci., 2013, 3(3), 1720-1726. 